\title{
PENGEMBANGAN APLIKASI MULTIMEDIA PEMBELAJARAN INTERAKTIF UNTUK MATA PELAJARAN BAHASA INDONESIA
}

\author{
Syamsiah \\ Program Studi Informatika, Universitas Indraprasta PGRI \\ Email: ncham.unindra08@gmail.com
}

\begin{abstract}
ABSTRAK
Perkembangan teknologi yang sangat pesat khususnya komputer, membawa dampak dalam dunia pendidikan dalam memanfaatkan komputer. Komputer dapat digunakan sebagai salah satu media pembelajaran yang interaktif. Untuk memudahkan dalam penyampaian materi pembelajaran kepada siswa maka materi ini dikemas secara menarik dalam bentuk multimedia yang bersifat mendidik dan menghibur bagi mereka. Tujuan penelitian ini adalah membuat aplikasi pembelajaran Bahasa Indonesia Interaktif berbasis multimedia sebagai alternatif media pembelajaran yang mudah dipelajari dan dipahami oleh siswa dengan konsep edutainmentpada Bimbel D-LLA COURSE. Aplikasi ini dibuat dengan menggunakan software Macromedia Flash.Pembuatan aplikasi ini menggunakan metode observasi dan studi pustaka.Berdasarkan hasil penelitian yang sudah dilakukan diperoleh kesimpulan bahwa aplikasi pembelajaran bahasa Indonesia Interaktif ini sudah berhasil dibuat yang terdiri dari enam menu yaitu : 4 jenis latihan (mengenal huruf di keyboard, belajar pemenggalan kata, tebak gambar dan menyusun huruf) dan 2 jenis permainan yaitu ( menangkap kata dalam telur, mencocokkan gambar dan kata) serta dilakukan pengujian kelayakan aplikasi mengunakan SQL.
\end{abstract}

Kata kunci:, Media pembelajaran, Bahasa Indonesia, Multimedia , Edutainment, SQL

ABSTRACT
The increasingly rapid development of technology, especially computer, creates an impact on the use of computer in education. Computers can be used as one of interactive learning media. To facilitate the delivery of learning materials to students, there must be an interesting packaging of materials in the form of multimedia that is educative and entertaining for them. The objective of this research is to make an application of interactive multimedia-based Indonesian language learning as an alternative learning medium that is easy to learn and understand by students with an edutainment concept at Bimbel D-LLA COURSE. The application is made by using software Macromedia Flash. It is made using observation and literature review methods. From the result of the research, it can be concluded that the application of interactive Indonesian language learning has been successfully made with six menus, namely: 4 types of exercises (knowing letters on keyboard, learning syllabification, guessing images and arranging letters) and 2 types of games (catching words on eggs, matching pictures and words). Besides, the fitness of this application has also been tested using SQL.

Keywords:Learning Media, Indonesian Language , Multimedia , Edutainment, SQL

\section{Pendahuluan}

Perkembangan teknologi yang pesat mempengaruhi peran sebuah komputer itu sendiri. Pada awalnya penggunaan komputer hanya difokuskan pada proses pengolahan data. Akan dijadikan sebagai media informasi dalam berbagai bidang salah satunya adalah bidang pendidikan.Pemanfaatan komputer sebagai media pembelajaran dalam dunia pendidikan sudah mulai digunakan di lembaga bimbingan belajar (bimbel). Sebagaimana seorang pengajar di suatu bimbel, komputer dapat digunakan sebagai media dalam proses belajar mengajar yang mempunyai fungsi sebagai media tutorial sehingga akan sangat membantu dalam proses penyampaian dan pemahaman terhadap materi yang disampaikan. 
Pemberian materi bahasa Indonesia pada bimbel sejauh ini hanyalah dengan sarana papan tulis dengan kapur atau pun spidol untuk memberikan contoh atau gambaran kepada siswa. Dengan penyampaian materi pelajaran seperti disebutkan diatas, kualitas ilmu yang tersampaikan kepada siswacenderung monoton dan kurang maksimal.Siswa cenderung sulit memahami ataupun menerima pelajaran terasa membosankan,kaku dan kurang interaktif.

Komputer yang memiliki kamampuan multimedia mampu menyajikan informasi secara audio visual yang menarik dan interaktif.Belajar dengan media komputer dapat diperkenalkan sejak dini kepada anak, yakni dengan programprogram aplikasi yang bersifat memadukan unsur pendidikan (education) dengan unsur hiburan (entertainment) atau sering dikenal dengan sebutan edutainment. Perpaduan tersebut akan melahirkan suasana belajar yang mengasyikkan bagi anak dengan tidak mengurangi nilai pembelajaran materi Bahasa Indonesia. Media pembelajaran bahasa Indonesia yang interaktif di sajikan dalam beberapa pemecahan masalah dari soal serta latihan-latihan dari materi yang ada.

Dengan menerapkan metode pembelajaran interaktif melalui aplikasi yang berfokus pada proses pembelajaran bahasa Indonesia yang dilakukan secara praktek langsung, maka diharapkan akan meningkatkan kualitas proses pembelajaran. Dalam dunia pendidikanpun manfaat multimedia sudah dirasakan oleh semua pihak khususnya siswa. Siswa dapat menggunakan fasilitas ini untuk melakukan pembelajaran secaran interaktif sehingga membuat pelajaran bahasa Indonesia menjadi lebih menarik dan mudah dipahami.

Tujuan penelitian ini adalah membuat suatu aplikasi pembelajaran bahasa Indonesia yang interaktif berbasis multimedia untuk lembaga bimbingan belajar (Bimbel) sebagai alternatif sistem pembelajaran yang menarik dan mudah dipahami oleh siswadengan konsep edutainment.

Penelitian ini diharapkan dapat memberikan manfaat baik secara teoretis maupun secara praktis.

a. Seara teoretis, penelitian ini dapat digunakan sebagai referensi alternatif dalam mengembangkan media pembelajaran interaktif yangdapat digunakan sebagai sarana belajar bahasa Indonesia.

b. Secara praktis:

1. Manfaat bagi pengajar dan bimbel, hasil penelitian ini berupa produk CD pembelajaran interaktif yang diharapkan dapat memberikan sumbangan pemikiran bagi para pengajar dan bimbel, sehingga produk ini dapat dijadikan bahan ajar bagi siswauntukbelajar bahasa indonesia dengan cara yang menyenangkan dan intraktif.

2. Manfaat bagi siswa, hasil penelitian ini diharapkan dapat meningkatkan pemahaman, rasa cinta dan bangga terhadap bahasa Indonesia.

3. Bagi peneliti, penelitian ini diharapkan dapat memperluas pengetahuan tentang pengembangan media pembelajaran interaktif yang dapat dijadikan sebagai sarana belajar siswa yang interaktif dan menyenangkan

\section{Tinjauan Pusataka}

\section{Pembelajaran Bahasa Indonesia}

Untuk mendapatkan pemahaman yang komprehensif tentang strategi pembelajaran Bahasa Indonesia dan efektivitasnya terhadap pencapaian tujuan belajar, kajian Pembelajaran Bahasa Indonesia ini akan difokuskan pada (1) pembelajaran bahasa, dan (2) strategi pembelajaran Bahasa Indonesia, meliputi metode dan teknik pembelajaran Bahasa Indonesia,

\section{a. Pembelajaran Bahasa}

Pembelajaran merupakan upaya membelajarkan siswa atau kegiatan pengupayaan ini akan mengakibatkan siswa dapat mempelajari sesuatu dengan cara efektif dan efisien. Upaya yang dilakukan dapat berupa analisis tujuan dan karakteristik studi dan siswa, 
analisis sumber belajar, menetapkan strategi pengorganisasian, isi pembelajaran, menetapkan strategi penyampaian pembelajaran, menetapkan strategi pengelolaan pembelajaran, dan menetapkan prosedur pengukuran hasil pembelajaran.

\section{b. Strategi Pembelajaran Bahasa Indonesia}

Pembicaraan mengenai strategi pembelajaran bahasa tidak terlepas dari pembicaraan mengenai pendekatan, metode, dan teknik mengajar.Secara umum strategi adalah suatu garis besar haluan dalam bertindak untuk mencapai tujuan yang sudah ditentukan (Pupuh \&Sobry, 2007: 3). Menurut Kemp (Senjaya, 2008) mengemukakan bahwa strategi pembelajaran adalah suatu kegiatan pembelajaran yang harus dikerjakan guru dan siswa supaya tujuan pembelajaran dapat dicapai secara efektif dan efisien, menurut (Sumarno, 2011) Strategi pembelajaran dapat diartikan sebagai kegiatan yang dipilih oleh pembelajar atau instruktur dalam proses pembelajaran yang dapat memberikan kemudahan fasilitas kepada pembelajar menuju kepada tercapainya tujuan pembelajaran tertentu yang sudah ditetapkan.

\section{Pendekatan Pembelajaran}

Istilah pendekatan dalam pembelajaran bahasa Indonesia mengacu pada teori-teori tentang hakekat bahasa dan pembelajaran bahasa Indonesia yang berfungsi sebagai sumber landasan/prinsip pengajaran bahasa Indonesia. Teori tentang hakikat bahasa Indonesia mengemukakan asumsi-asumsi tentang hakikat bahasa, karakteristik bahasa, unsur-unsur bahasa, serta fungsi dan pemakaiannya sebagai media komunikasi dalam suatu masyarakat bahasa. Menurut Anthony (Slamet, 2007: 50) pendekatan mengacu kepada seperangkat asumsi yang saling berkaitan dan berhubungan dengan pengajaran.Pendekatan merupakan dasar teoritis untuk suatu metode.

\section{Metode Pembelajaran}

Istilah metode berarti perencanaan secara menyeluruh untuk menyajikan materi pelajaran bahasa secara teratur. Istilah ini bersifat prosedural, dalam arti penerapan suatu metode dalam pembelajaran bahasa dikerjakan dengan melalui langkah yang teratur dan secara bertahap, dimulai dari penyusunan perencanaan pengajaran, penyajian pengajaran, proses belajar mengajar dan penilaian hasil belajar. Metode pembelajaran berarti carayang dipakai oleh guru agar tujuan pembelajaran dapat dicapai secara efektif dan efesien. Menurut (Sutikno, 2009: 88).Metode pembelajaran adalah cara menyajikan materi pelajaran yang dilakukan oleh pendidik agar terjadi proses pembelajaran pada diri siswa dalam upaya untuk mencapai tujuan.

\section{Teknik Pembelajaran}

Teknik adalah jalan, alat, atau media yang digunakan oleh guru untuk mengarahkan kegiatan siswa kearah tujuan yang ingin dicapai. Dalam kamus Besar Bahasa Indonesia, teknik diartikan sebagai metode atau sistem mengerjakan sesuatu, cara membuat atau melakukan sesuatu yang berhubungan dengan seni (2005: 1158).Istilah teknik dalam pembelajaran bahasa mengacu pada pengertian implementasi perencanaan pengajaran di depan kelas, yaitu penyajian pelajaran dalam kelas tertentu dalam jam dan materi tertentu pula. Teknik mengajar berupa berbagai macam cara, kegiatan, dan kiat (trik) untuk menyajikan pelajaran dalam rangka mencapai tujuanpembelajaran. Teknik pembelajaran bersifat implementasi, individual dan situasional.

\section{Pengertian Media Pembelajaran}

Media adalah bentukjamak dari medium yang berasal dari bahasa latin medius yang berarti 
tengah. Dalam bahasa Indonesia kata medium diartikan sebagai "antara' atau "sedang" untuk menjelaskan media pembelajaran adalah segala sesuatu yang dapat digunakan untuk menyalurkan pesan dari pengirim ke penerima pesan. Berdasarkan pernyataan tersebut dapat disimpulkan bahwa media pembelajaran adalah alat bantu yang digunakan oleh guru sebagai alat bantu mengajar. Berdasarkan beberapa pendapat di atas, dapat disimpulkan pengertian media pembelajaran sebagai alat bantu mengajar untuk menyampaikan materi agar pesan lebih mudah diterima dan menjadikan siswa lebih termotivasi dan aktif.

\section{Pengertian Multimedia}

Multimedia berasal dari teater, yaitu pertunjukan yang memanfaatkan lebih dari satu medium di panggung yang mencakup monitor video, synthesized band, dan karya seni manusia sebagaibagian dari pertunjukan. Pengertian kedua mensyaratkan adanya sinkronisasi berbagai media tadi dengan bantuan komputer, Membedakkan dengan pengertian multimedia yang pertama yang memanfaatkan berbagai media yang terpisah dan berdiri sendiri (Hamalik, 2005:34).

\section{Unsur-Unsur Multimedia}

Multimedia memiliki unsur sebagai berikut (Haryadi, 2006:10) Teks Bentuk data multimedia yang paling mudah disimpan dan dikendalikan adalah teks. Kebutuhan teks bergantung pada kegunaan aplikasi multimedia.

\section{a. Gambar}

Gambar dapat meringkas dan menyajikan data kompleks dengan cara yang baru dan lebih berguna. Gambar sering kali muncul sebagai backdrop (latar belakang) yang mempermanis teks.

\section{b. Audio}

Multimedia tanpa bunyi hanya disebut unimedia, bukan multimedia. Masing-masing kemampuan membutuhkan teknologi,perangkatkeras, dan perangkat lunak untuk menjalankannya. Ada tigabelas jenis objek bunyi yang bisa digunakan dalam produksi multimedia, yakni format waveform audio, aiff dat, ibf, mod, rni, sbi, snd, voc, au, MIDI soundtrack, compact disk audio, dan MP3 file.

\section{c. Video}

Video menyediakan sumber daya yang kaya dan hidup bagi aplikasi multimedia. Ada empat macam video yang dapat digunakan sebagai objek link dalam aplikasi multimedia :live video feeds, videotape, videodisc, dan digital video.

\section{d. Animasi}

Dalam multimedia, animasi merupakan penggunaan komputer untuk menciptakan gerak pada layar. Ada Sembilan macam yaitu animasi sel, animasi frame, animasi sprite, animasilintasan, animasi splin, animasi vector, animasi karakter, animasi computational, dan morphing.

\section{Macromedia Flash}

Macromedia Flash merupakan aplikasi yang digunakan untuk melakukan desain dan membangun perangkat presentasi, publikasi, atau aplikasi lainnya yang membutuhkan ketersediaan sarana interaksi dengan penggunanya. Proyek yang dibangun dengan Flash bias terdiri atas teks,gambar,animasi sederhana, video, atau efek-efek khusus lainnya.

Dikse (2010:1) berpendapat bahwa Macromedia Flash dibuat oleh perusahaan software macromedia untuk keperluan membuat suatu aplikasi webyang interaktif dan menarik. 
Macromedia Flash sering digunakan untuk membuat animasi dan untuk keperluan lain seperti membuat game dan tutorial. Karena Macromedia dapat menampilkan teks, gambar, animasi, dan audio secara bersama maka sangat mungkin apabila Macromedia Flash digunakan sebagai sarana pengembangan media pembelajaran. Dapat disimpulkan bahwa Macromedia Flash merupakan software yang dapat dikembangkan menjadi media pembelajaran yang interaktif.

\section{Software Quality Assurance (SQA)}

Untuk memastikan bahwa perangkat lunak yang dibuat memiliki standar minimal kualitas, maka salah satu metode untuk pengukuran kualitas perangkat lunak secara kuantitatif adalah metode SQA (Software Quality Assurance).

Tabel.1 Metric of Software Quality Assurance (SQA)

\begin{tabular}{llll}
\hline No & Metrik & Deskripsi & Bobot \\
\hline 1 & Auditability & Memenuhi standard atau tidak & 0.1 \\
2 & Accuracy & Keakuratan komputasi & 0.15 \\
3 & Completeness & Kelengkapan & 0.1 \\
4 & Error Tolerance & Toleransi terhadap kesalahan & 0.1 \\
5 & Execution Efficiency & Kinerja Eksekusi & 0.1 \\
6 & Operability & Kemudahan untuk dioperasikan & 0.15 \\
7 & Simplicity & Kemudahan untuk difahami & 0.15 \\
8 & Training & Kemudahan pembelajaran fasilitas Help & 0.15 \\
\hline
\end{tabular}

Ada 8 buah kriteria yang dapat digunakan untuk mengukur kualitas sebuah perangkat lunak secara kuantitatif.Seperti terlihat pada table.1

\section{Metodologi Penelitian}

\section{Metode Pengumpulan Data}

a. Diskusi Interaktif

Diskusi interaktif merupakan metode pengumpulan data dengan cara mengajukan pertanyaan secara lisan kepada pihakyang bersangkutan.Dalam hal ini pihak Bimbel Dlla Cause sebagai objek penelitian.

b. Studi Kepustakaan

Studi pustaka adalah penelitian untukmencari teori/konsep/generalisasi yang dapat digunakan sebagai landasan teori dalam penelitian.Untukmencari metodologi yang sesuai dilakukan dengan teknik membandingkan antara teori yang ada dengan fakta dilapangan. Literatur yang didapat oleh penulis adalah modul referensi yang digunakan guru, jurnal ilmiah dan data yang diperoleh dari internet dengan sumber terpercaya.

c. Kuisioner

Kuisioner merupakan teknik pengumpulan data yang dilakukan dengan cara memberi seperangkat pertanyaan atau pernyataan tertulis kepada responden untuk dijawabnya. Responden yang dimaksud disini yaitu pengajar dan pemilik bimbel.

\section{Sumber Data}

a. Sumber literature

Pengumpulan materi mata pelajaran diambil dari modul yang sudah dipakai dalam yanglain. Pengambilan script serta pedoman pembuatan modul interaktif diambil dari beberapa buku-buku panduan belajar macromedia flash.

b. Sumber data primer

Cara pengambilan sumber data primer di sini adalah mengambil data dengan 
menggunakan. Angket ini digunakan untuk mendapatkan data tentang kelayakan penggunaan aplikasi pembelajaran bahasa Indonesia yang interaktif berbasis multimedia sebagai media dalam proses belajar mengajar.

\section{Hasil dan Pembahasan}

Produk penelitian yang dihasilkan adalah Perancangan Media Pembelajaran Interakif untuk mata pelajaran bahasa Indonesia. Pelajaran yang diberikan melalui 2 cara yaitu :

\section{a. Latihan,terdiri dari $\mathbf{4}$ jenis latihan yaitu :}

1. Mengenal Huruf di Keyboard

2. Belajar Pemenggalan Kata

3. Tebak Gambar

4. Menyusun Huruf

\section{b. Permainan, terdiri dari 2 jenis permainan yaitu :}

1. Kata dalam Telur

2. Mencocokkan Gambar dan Kata

Aplikasi " aplikasi media pembelajaran bahasaIndonesia yang interaktif berbasis multimedia" memiliki antarmuka sebagai berikut :

\section{Tampilan Pembuka}

Tampilan pembuka muncul pada saat pengguna membuka program pertama kali.

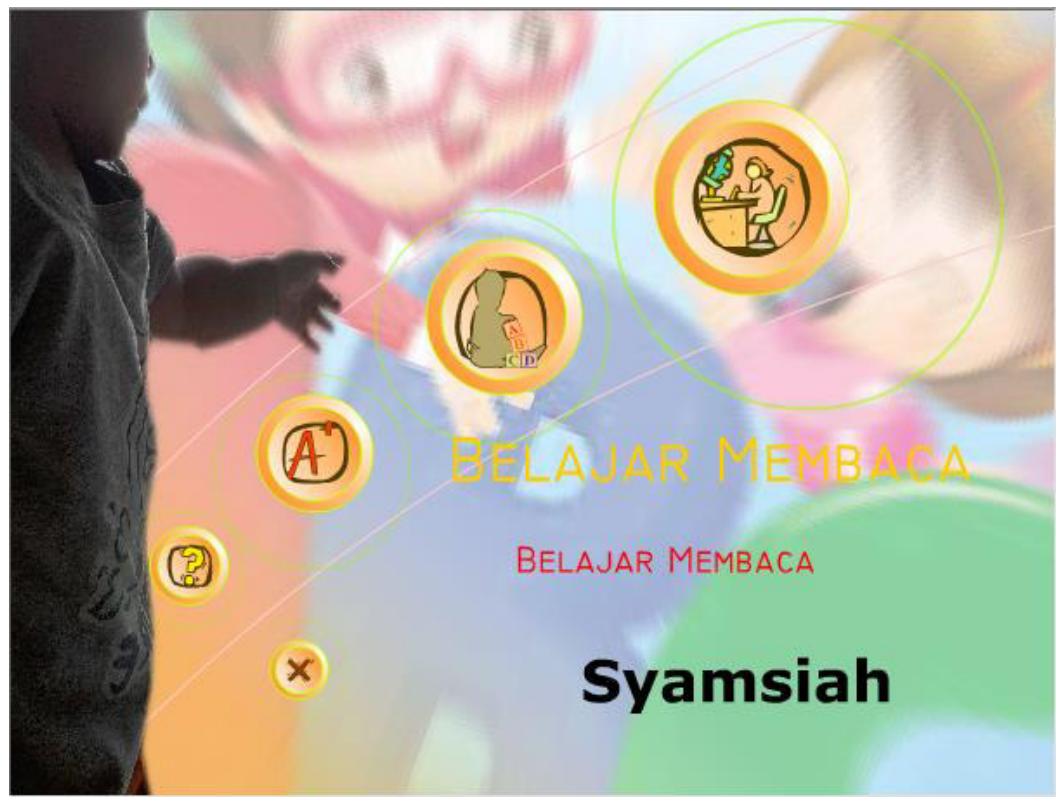

Gambar 1. Tamplan Menu Utama

\section{Menu Utama}

Menu utama merupakan bagian utama dari aplikasi dimana terdapat 5(lima) tombol navigasi dari submenu lainnya. Tombol navigasi tersebut adalah:

\section{a. Tombol Latihan}

Apabila tombol latihan ditekan, maka halaman akan berganti ke menu latihan. Menu latihan memiliki 4 (empat) jenis latihan yang dapat dimainkan. Sebaiknya pengguna memulai latihan secara urut dimulai dari latihan 1.Pada halaman menu latihan dan halaman masing- masing latihan terdapat tombol kembali. 


\section{b. Tombol Permainan}

Apabila tombol permainan ditekan, maka halaman akan berganti ke menu permainan. Menu permainan memiliki 2 (dua) jenis permainan yang dapat dimainkan.Pada halaman menu permainan dan halaman masing- masing permainan terdapat tombol kembali.

\section{c. Tombol Daftar Nilai}

Apabila tombol daftar nilai ditekan, maka halaman akan berganti ke halaman daftar nilai. Halaman daftar nilai adalah daftar nilai 10 (sepuluh) terbaik yang diperoleh oleh pengguna dalam setiap menu. Pada halaman ini terdapat tombol kembali.

\section{d. Tombol Bantuan}

Apabila tombol bantuan ditekan, maka halaman akan berganti ke menu bantuan. Menu bantuan berisikan informasi singkat pemakaian aplikasi online "educational game belajar membaca dan menulis untuk pemula".

\section{e. Tombol Keluar}

Apabila tombol keluar ditekan, pengguna akan keluar dari aplikasi.

\section{Menu Latihan}

Pada menu latihan terdapat 4 (empat) tombol navigasi, bila tombol ditekan maka halaman akan berganti ke latihan yang sudah dipilih. Pilihan latihan tersebut adalah:

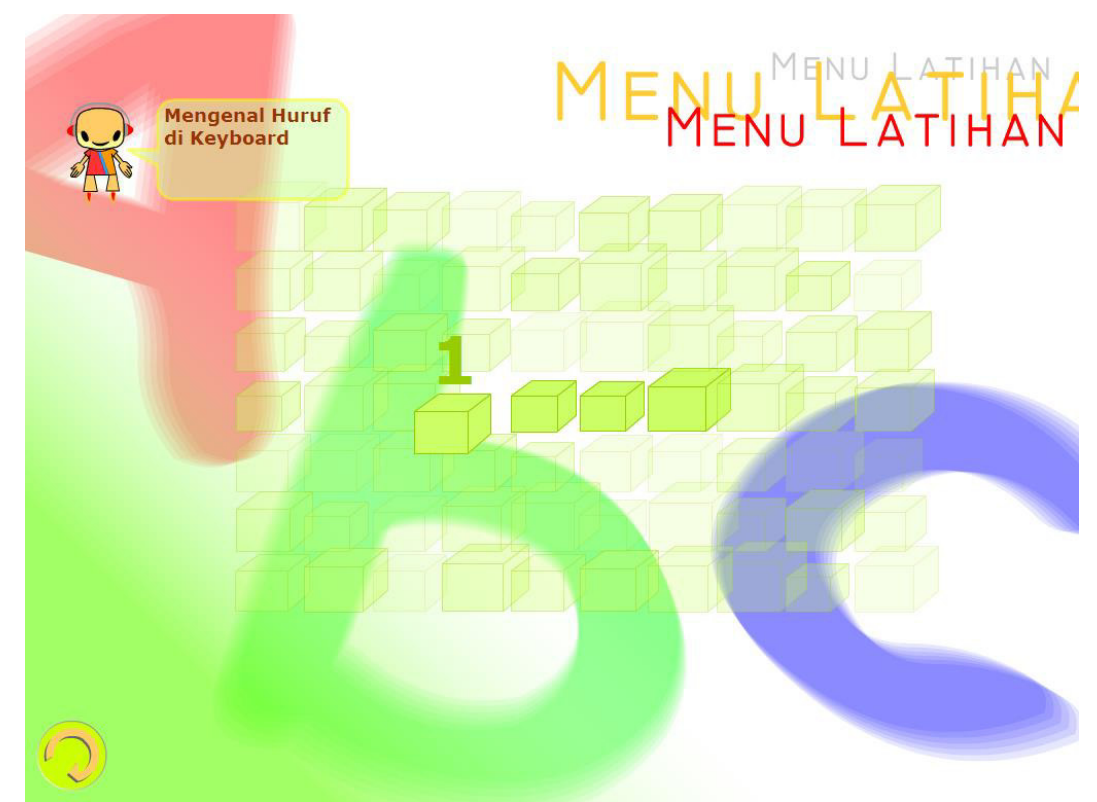

Gambar 2. Tamplan Menu Latihan

\section{a. Mengenal Huruf di Keyboard}

Latihan ini bermaksud untuk mengajarkan pengguna dalam mengenal huruf dalam abjad, dan penggabungan huruf.Gambar keyboard sebagai petunjuk huruf yang muncul, suara akan dibunyikan sesuai dengan huruf yang muncul. Pemberian soal dibuat secara terurut kemudian soal diacak. Pada latihan ini, terdapat total waktu dan nilai yang sudah ditempuh selama latihan yang akan tercatat dalam daftar nilai bila memperoleh total terbaik. Setiap memulai latihan dan pindah soal berikutnya, pengguna diminta menekan spasi. 


\section{b. Belajar Pemenggalan Kata}

Latihan ini bermaksud mengajarkan pengguna cara memenggal kata untuk mempermudah proses membaca secara utuh. Latihan ini dibagi menjadi 2 (dua) level yaitu :

\section{Level 1}

Dalam penyampaiannya digunakan gambar, teks dan suara. Gambar yang muncul disertai dengan tulisan dari nama gambar tersebut. Pengguna diminta menirukan tulisan di tempat/ kotak yang sudah disediakan yang secara otomatis sudah dipenggal.Pemberian soal dibuat secara terurut dengan peningkatan kosakata berdasarkan kesulitan pembacaan.

\section{Level 2}

Dalam penyampaiannya digunakan gambar dan suara. Gambar yang muncul tidak disertai dengan tulisan dari nama gambar tersebut. Pengguna diminta menuliskan nama dari gambar tersebut pada tempat/ kotak yang sudah disediakan yang secara otomatis sudah dipenggal. Pada level ini, merupakan pengulangan materi level 1 dan penambahan kosakata baru untuk memperbanyak pembendaharaan kata.Pemberian soal dibuat secara acak. Pada latihan ini, setiap 1 (satu) huruf yang dituliskan benar, suara akan dibunyikan. Tetapi bila tulisan salah, suara tidak dibunyikan sampai pengguna menuliskan huruf dengan benar. Terdapat total waktu dan nilai yang sudah ditempuh selama latihan yang akan tercatat dalam daftar nilai bila memperoleh total terbaik.Setiap memulai latihan dan pindah soal berikutnya, pengguna diminta menekan spasi.

\section{c. Tebak Gambar}

Latihan ini bermaksud menghapalkan bentuk serta memahami gambar dan kata yang sudah diberikan pada latihan 1 (satu) dan 2 (dua).Dalam penyampaiannya digunakan gambar dan teks dimana pengguna diberikan soal pilihan ganda yang dapat dipilih salah satu jawaban yang dianggap benar dan pemberian soal dibuat secara acak. Pada latihan ini, terdapat total waktu dan nilai yang sudah ditempuh selama latihan yang akan tercatat dalam daftar nilai bila memperoleh total terbaik.Setiap memulai latihan dan pindah soal berikutnya, pengguna diminta menekan spasi.

\section{d. Menyusun Huruf}

Latihan ini bermaksud mengasah kemampuan untuk menyusun huruf- huruf yang sudah diacak sesuai dengan suara yang dibunyikan.Terdapat 2 (dua) level pada latihan ini yaitu :

\section{Level 1}

Dalam penyampaiannya digunakan gambar, teks dan suara.Terdapat gambar, hurufhuruf yang sudah diacak dan suara yang dibunyikan.Pengguna diminta menyusun huruf- huruf tersebut sesuai dengan gambar dan suara yang dibunyikan.Pada level ini, ditambahkan materi kosakata baru untuk memperbanyak pembendaharaan kata yang berguna dalam proses belajar membaca.

\section{Level 2}

Dalam penyampaiannya digunakan teks dan suara.Huruf- huruf yang sudah diacak muncul beserta suara yang sudah dibunyikan.Pengguna diminta menyusun hurufhuruf tersebut sesuai dengan suara yang dibunyikan. Pada level ini materi yang diberikan merupakan pengulangan materi level 1.Pada latihan ini, terdapat total waktu dan nilai yang sudah ditempuh selama latihan yang akan tercatat dalam daftar nilai bila memperoleh total terbaik.Setiap memulai latihan dan pindah soal 
berikutnya, pengguna diminta menekan spasi.

\section{Menu Permainan}

Pada menu permainan terdapat 2 (dua) tombol navigasi, bila tombol ditekan maka halaman akan berganti ke permainan yang sudah dipilih. Pilihan permainan tersebut adalah :

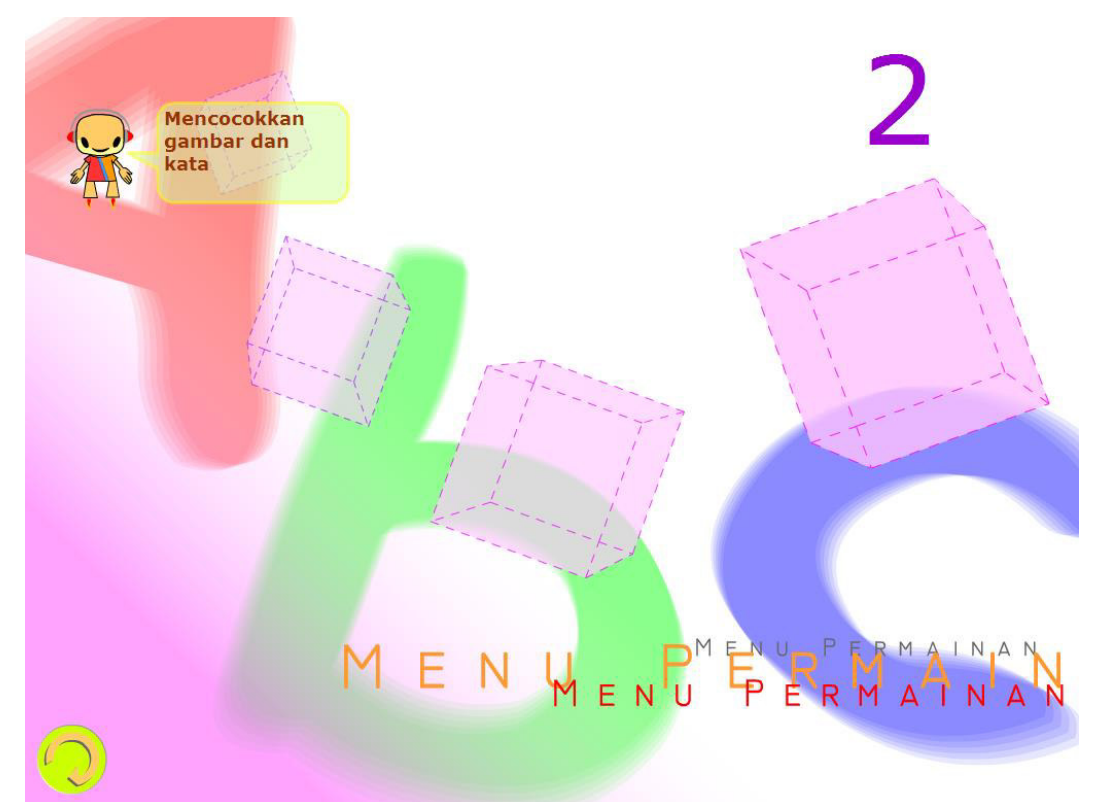

\section{Gambar 3. Tamplan Menu Permainan}

\section{a. Menangkap Kata Dalam Telur}

Permainan ini bermaksud untuk memperdalam kosakata yang sudah diberikan selama latihan lewat permainan.Pada permainan ini, soal yang muncul berupa tulisan dan suara dimana pengguna diminta untuk menuliskan kata yang ada pada telur.Kecepatan dan jarak antara masing- masing soal yang muncul semakin cepat dan dekat.Pengguna tidak diharuskan menjawab soal dari yang pertama kali muncul.Materi yang diberikan merupakan pengulangan yang terdapat pada materi latihan. Pada permainan ini, terdapat total waktu dan nilai yang sudah ditempuh selama permainan yang akan tercatat dalam daftar nilai bila memperoleh total terbaik.Setiap memulai permainan dan pindah soal berikutnya, pengguna diminta menekan spasi.

\section{b. Mencocokkan Gambar dan Kata}

Permainan ini bermaksud untuk menghapal bentuk dan memahami gambar dengan memasangkan setiap gambar dengan kata yang sesuai. Pada permainan ini, soal yang diberikan merupakan pengulangan dari kosakata pada latihan dengan menambahkan kosakata baru untuk menambah pembendaharaan kata. Setiap ditemukan gambar dan kata yang sesuai, suara akan dibunyikan.Pada permainan ini, terdapat total waktu dan nilai yang sudah ditempuh selama permainan yang akan tercatat dalam daftar nilai bila memperoleh total terbaik.Setiap memulai permainan dan pindah soal berikutnya, pengguna diminta menekan spasi. 


\section{Menu Level}

Menu level terdapat pada latihan pemenggalan kata dan latihan menyusun huruf. Pada menu ini terdiri dari 2 (dua) tombol navigasi yaitu tombol level 1 dan tombol level 2.

\section{Tombol Kembali}

Tombol kembali terdapat pada setiap masing- masing halaman yang berfungsi untuk kembali ke halaman yang sudah dibuka sebelumnya.

\section{Hasil Pengujian Sistem}

Analisis Aplikasi (SQA)

Untuk mengetahui kualitas aplikasi pembelajaran bahasa Indonesia yang interaktif berbasismultimediamaka digunakan Software Quality Assurance (SQA). Komponen dari SQA yang digunakan pada pengujian ini dapat dilihat pada tabel.1.Ada 5 komponen dalamsoftware quality assurance (SQA) yang digunakan. Dari 5 komponen tersebut Auditability (0.25), Completeness (0.15), Operability (0.25),Simplicity (0.15) dan Training (0.25) akan dibuat 5 pertanyaan untuk angket yang akan disebarkan kepada 5 orang pengamat yang merupakan user yang diambil secara acak.

Tabel 2. Hasil Evaluasi Software Quality Assurance (SQA)

\begin{tabular}{lllllll}
\hline \multirow{2}{*}{ User } & \multicolumn{2}{l}{ Skor Metrik } & & & Skor \\
& 1 & 2 & 3 & 4 & 5 & \\
\hline 1 & 100 & 80 & 80 & 100 & 100 & 97 \\
2 & 100 & 80 & 80 & 60 & 100 & 91 \\
3 & 100 & 80 & 100 & 80 & 80 & 94 \\
4 & 80 & 60 & 80 & 100 & 80 & 84 \\
5 & 100 & 60 & 80 & 100 & 100 & 94 \\
\hline Rata-Rata & & & & & & 92 \\
\hline
\end{tabular}

$$
\begin{aligned}
& \text { Skor } 1=(100 * 0.25)+(80 * 0.15)+(80 * 0.25)+(100 * 0.15)+(100 * 0.25)=97.00 \\
& \text { Skor } 2=(100 * 0.25)+(80 * 0.15)+(80 * 0.25)+(60 * 0.15)+(100 * 0.25)=91.00 \\
& \text { Skor3 }=(100 * 0.25)+(80 * 0.15)+(100 * 0.25)+(80 * 0.15)+(80 * 0.25)=94.00 \\
& \text { Skor4 }=(80 * 0.25)+(60 * 0.15)+(80 * 0.25)+(100 * 0.15)+(80 * 0.25)=84.00 \\
& \text { Skor5 }=(100 * 0.25)+(60 * 0.15)+(80 * 0.25)+(100 * 0.15)+(100 * 0.25)=94.00 \\
& \text { Rata-rata }=((97.00)+(91.00)+(94.00)+84.00)+(92.00)) / 5=92.00
\end{aligned}
$$

Skor rata-rata yang dihasilkan adalah 92.00, sedangkan nilai optimal untuk sebuah perangkat lunak yang memenuhi standar kualitas berdasarkan uji SQA adalah 80.00

\section{Simpulan Dan Saran \\ Simpulan}

Kesimpulan yang dapat diambil dari penelitian tentang Aplikasi Media Pembelajaran Bahasa Indonesia Interaktif adalah sebagai berikut :

1. Sudah dihasilkan sebuah produk penelitian berupa "Aplikasi Multimedia Pembelajaran"dan sudah digunakan oleh pengajarmata pelajaranbahasa indonnesia di bimbel D-LLA.

2. Aplikasi berbasis multimedia ini dianggap layak berdasarkan nilai skor 92.00 , sehingga dapat digunakan untuk membantu Guru dalam menyampaikan materi dan juga 
miminimalkan rasa bosan siswa karena pelajaran dikelas yang monoton dengan konsep edutainment.

\section{Saran}

Dalam pembuatan aplikasi pembelajaran bahasa Indonesia yang interaktif berbasis multimedia ini belumlah sempurna. Penulis menyadari masih banyak kekurangan yang terdapat pada aplikasi pembelajaran Bahasa Indonesia ini. Oleh sebab itu penulis berharap penelitian inidapat dilanjutkan untuk mendapatkan hasil yang lebih baik dari sebelumnya. Berikut adalah saran yang dapat diberikan untuk pengembangan aplikasi pembelajaran bahasa Indonesia yang interaktif berbasis, yakni:

a. Memberikan tampilan animasi yang lebih menarik dan lebih interaktif.

b. Menambah fitur-fitur pembelajaran pada aplikasi misalnya sinonin, Antonim dan lainnya.

c. Menambah jumlah level/ tingkat padatiap tipe soal.

\section{Daftar Pustaka}

Departemen Pendidikan Nasional RI. . (2005). Pedoman Perpustakaan Perguruan Tinggi Jakarta: Departemen Pendidikan Nasional RI Direktorat Jendral Pendidikan Tinggi.

Dikse, I Wayan. (2010).Animasi dengan Flash 8.Yogyakarta: Graha Ilmu

Hamalik, Umar.(2005).Psikologi Belajar dan Mengajar. Bandung: Sinar Baru.

Haryadi. (2006).Pengembangan Media Pembelajaran KimiaBerbantuan Komputer

Tentang Kimia Unsur Untuk Siswa Kelas XII. Yogyakarta: UNY.

Machfudz, Imam. (2002). Metode Pengajaran Bahasa IndonesiaKomunikatif. Jurnal Bahasa dan Sastra UM

Puput, F., \&Sutikno, M., S., (2007). Strategi Belajar Mengajar Melalui Penanaman Konsep Umum \& Kosep Islami. Bandung: PT RefikaAditama

Sanjaya, Winna. (2008) Strategi Pembelajaran Berorientasi Standar Proses Pendidikan. Jakarta : Kencana Prenada Media Grouf

Sumarno, Alim. (2011). Pemanfaatan ICT Dalam Proses Merancang Dan.Mengimplementasikan Model Pembelajaran Inovatif Designed Student. Centred2011Strategi PembelajaranInovatif Kontemporer. Jakarta: PT.Bumi Aksara.

Slamet St. Y., (2007).Dasar-dasar Pembelajaran Bahasa dan Sastra Indonesia di Sekolah. Dasar, Surakarta: LPP UNS, hal. 50.

Sutikno, M. Sobry, (2009). Belajar dan Pembelajaran, Prospect. Bandung: PT RefikaAditama 